\title{
Hubungan Kadar Apelin dengan Disfungsi Diastol pada Penderita Gagal Jantung dengan Fraksi Ejeksi Normal
}

\author{
Dini Rostiati, ${ }^{1}$ Erwinanto, Achmad Fauzi Yahya, ${ }^{2}$ Chaerul Achmad, Pintoko Tedjokusumo, ${ }^{2}$ \\ Syarief Hidayat, ${ }^{2}$ Augustine Purnomowati, ${ }^{2}$ Toni Mustahsani Aprami ${ }^{2}$ \\ ${ }^{1}$ Rumah Sakit Umum Daerah Kota Bandung, ${ }^{2}$ Departemen Kardiovaskular Fakultas Kedokteran Universitas \\ Padjadjaran/Rumah Sakit Dr. Hasan Sadikin Bandung
}

\begin{abstract}
Abstrak
Apelin merupakan peptida yang berperan dalam mempertahankan performa jantung pada beban tekanan kronik. Penelitian ini bertujuan menilai hubungan antara kadar apelin dan disfungsi diastol pada penderita gagal jantung dengan fraksi ejeksi normal. Analisis statistik korelasi Spearman-Rank. Penelitian dilakukan di Instalasi Rawat Jalan Jantung dan Divisi Diagnostiik Noninvasif Departmen Kardiologi dan Kedokteran Vaskular Rumah Sakit Dr. Hasan Sadikin Bandung periode Januari-April 2014. Hasil penelitian didapatkan 50 penderita laki-laki sebanyak 24 (48\%) dan perempuan 26 (52\%), usia rata-rata 58,72 (11,02) tahun, durasi hipertensi 1-30 tahun, median 5 tahun. Indeks massa tubuh rata-rata 24,13 kg/m². Median tekanan darah sistol 130 (120-180) mmHg dan median tekanan darah diastol 90 (70-110) mmHg. Fraksi ejeksi median 65 (49-77\%), pengobatan dengan angiotensin converting enzyme inhibitor (ACEI) sebanyak 48\%, calcium channel blocker (CCB) 27\%, beta bloker 6\%, angiotensin receptor blocker (ARB) 3\%, dan diuretik 1\%. Pengukuran fungsi diastol, tissue doppler imaging (TDI) rata-rata 10,32, deceleration time rata-rata 228,2 detik, median rasio E/A (early/atrial (late) ventricular filling velocities) 0,77 (0,43-1,53), median isovolumic relaxation time (IVRT) 92 (60-177) detik. Median kadar apelin 1080,5 (993,2-1113) pg/mL. Terdapat korelasi positif antara kadar apelin dan disfungsi diastol yang dihitung dengan TDI $(\mathrm{R}=0,3445, \mathrm{p}=0,014)$. Sebagai simpulan, apelin dapat digunakan untuk menilai gejala dan prognosis pada penderita gagal jantung dengan fraksi ejeksi normal karena kadarnya meningkat pada beban tekanan disertai fibrosis yang sedikit dan menurun pada beban tekanan disertai fibrosis yang luas. [MKB. 2015;47(2):96-101]
\end{abstract}

Kata kunci: Apelin, disfungsi diastol, fraksi ejeksi normal, gagal jantung, TDI

\section{Correlation between Plasma Apelin Level and Diastolic Dysfunction in Heart Failure Patients with Preserved Ejection Fraction}

\begin{abstract}
Apelin ia a novel multifunction peptide implicated in cardiovascular performance regulation in chronic pressure overload. Plasma apelin level and its correlation to diastolic dysfunction in patient heart failure with preserved ejection fraction were investigated. Hypertensive patients with heart failure but without coronary artery disease, atrial fibrillation, obese, and diabetes mellitus were enrolled in this study during January-April 2014. Each patients underwent plasma apelin measurement and echocardiographic assessment of left ventricular diastolic function. Statistical analysis was conducted using Spearman Rank. Fifty patients, 24 males (48\%) and 26 females (52\%), met the inclusion criteria. The mean age of the participants was 58.72 (11.02) years with a duration of hypertension between 1-30 years, median 5 years. Mean body mass index was $24.13 \mathrm{~kg} / \mathrm{m}^{2}$. Systolic blood pressure median was 130 (120-180) $\mathrm{mmHg}$ while the diastolic blood pressure median was $90(70-110) \mathrm{mmHg}$. Left ventricular ejection fraction median was 65 (49-77)\%, treatment with angiotensin converting enzyme inhibitor (ACEI) was $48 \%$, calcium channel blocker (CCB) was $27 \%$, beta blocker was $6 \%$, angiotensin receptor blocker (ARB) was $3 \%$, and diuretic was $1 \%$. Diastolic function assessment with tissue doppler imaging (TDI) resulted in a mean of 10.32, deceleration time mean of 228.2, E/A (early/atrial (late) filling velocities) ratio median of 0.77 (0.43-1.53),and IVRT (isovolumic relaxation time) median of 92 (59-177). Plasma apelin measurement median was 1,080.5 (993.2-11) pg/mL. There was a positive correlation between plasma apelin level and diastolic function (TDI) $(\mathrm{R}=0.3445, \mathrm{p}=0.014)$. There was no significant correlation between plasma apelin level and diastolic function using other criteria. In conclusion, apelin can be used for assessing symptoms and prognosis of heart failure patients with preserved ejection fraction because apelin level is upregulated when pressure overload occurs with less fibrosis and down-regulated when pressure overload occurs with marked fibrosis. [MKB. 2015;47(2):96-101]
\end{abstract}

Key words: Apelin, diastolic dysfunction, heart failure, preserved ejection fraction

Korespondensi: Dini Rostiati, dr., Rumah Sakit Umum Daerah Ujung Berung Kota Bandung Jalan Rumah Sakit No. 22 Bandung, mobile 082116953448, e-mail:dr_dini020180@yahoo.com 


\section{Pendahuluan}

Gagal jantung merupakan salah satu masalah kesehatan dengan angka kesakitan dan kematian yang cukup tinggi di seluruh dunia, termasuk di Indonesia. Survei epidemiologi gagal jantung di Asia menyatakan bahwa prevalensi gagal jantung di China adalah $1,26 \%$ dari seluruh populasi, di Malaysia bahwa dari 1.435 angka kujungan ke rumah sakit, 6,7\% adalah penderita gagal jantung, di Jepang bahwa terdapat 1 juta orang yang menderita gagal jantung pada tahun 2012 $(0,7 \%$ dari seluruh populasi). Indonesia belum memiliki data pasti tentang prevalensi penyakit jantung, di RS Jantung Harapan Kita setiap hari ada sekitar 400-500 penderita berobat jalan dan sekitar $65 \%$ adalah penderita gagal jantung. ${ }^{1,2}$ Registri di Asia, yaitu di Jepang menyatakan bahwa lebih dari separuh $(65,2 \%)$ penderita gagal jantung memiliki fraksi ejeksi ventrikel kiri yang normal atau mendekati normal dan dikenal dengan istilah heart failure with preserved ejection fraction (HFPEF) dengan hipertensi dan usia tua sebagai faktor risiko utama. Penelitian skala besar mengenai gagal jantung di Eropa menyatakan bahwa penderita gagal jantung dengan fraksi ejeksi normal memiliki angka kematian yang sama seperti pada penderita gagal jantung dengan penurunan fraksi ejeksi. ${ }^{3,5,8}$

Hipertensi merupakan faktor risiko yang paling sering dijumpai pada kasus gagal jantung dengan fraksi ejeksi normal, yaitu hampir semua penderita gagal jantung dengan fraksi ejeksi normal ternyata memiliki hipertensi. ${ }^{4,6-8}$ Progresivitas penyakit jantung hipertensi atau hypertensive heart disease menuju gagal jantung dengan fraksi ejeksi normal merupakan topik yang menarik yang sedang banyak diteliti saat ini. ${ }^{6,8}$ Pada penderita hipertensi, terjadi suatu kondisi pressure overload atau beban tekanan kronik yang menyebabkan perubahan struktural dan fungsional jantung. ${ }^{8}$

Perbedaan yang signifikan baik secara struktural maupun fungsional didapatkan pada gagal jantung dengan disfungsi sistol dan diastol, namun tampilan klinis di antara keduanya adalah sama yaitu terdapat tanda dan gejala gagal jantung. ${ }^{6,8}$ Proses fibrosis dan kerusakan sel-sel otot jantung terjadi berbeda, baik pada gagal jantung dengan fraksi ejeksi normal atau menurun. ${ }^{7,8}$

Apelin merupakan ligand endogen dari reseptor APJ yang merupakan salah satu dari kelompok $G$ protein coupled receptors (GPCRs) yang mempunyai peran di dalam mengontrol fungsi jantung. ${ }^{20,21}$ Apelin dihasilkan oleh sel- sel otot jantung yang mempunyai efek yang menguntungkan untuk jantung yaitu sebagai vasodilator, dapat meningkatkan kontraktilitas miokardium, meningkatkan curah jantung, dan mempertahankan performa jantung saat terjadi stres kardiovaskular, misalnya pada keadaan pressure overload atau beban tekanan yang kronik. ${ }^{9,10}$

Apelin meningkat secara bermakna pada kondisi beban tekanan kronik dibanding dengan kondisi normal dan menurun secara bermakna pada disfungsi sistol dengan penurunan yang signifikan terjadi pada jantung yang mengalami fibrosis dan kerusakan otot jantung yang paling berat. $^{10,11}$

Penelitian pada binatang yang mengalami hipertensi dan juga beban tekanan yang kronik menyatakan bahwa kadar apelin akan meningkat pada fase awal terjadinya beban tekanan yang tinggi $(<12$ minggu $)$ dan menjadi normal atau penurunan pada fase selanjutnya $(>12$ minggu) dengan penurunan yang seiring dengan menurunnya fungsi jantung dan bertambahnya kerusakan pada sel-sel otot jantung. ${ }^{11,12}$

Penelitian lain yang meneliti kadar apelin pada gagal jantung dengan berbagai akibat menyatakan bahwa kadar apelin meningkat atau normal pada penderita gagal jantung dengan hipertrofi ventrikel kiri, namun menurun pada gagal jantung dengan dilatasi ventrikel kiri. ${ }^{11,13}$ Dari penelitian-penelitian tersebut dapat diambil simpulan bahwa kadar apelin meningkat pada kondisi pressure overload atau beban tekanan yang tinggi (hipertensi dan disfungsi diastol) dan menurun pada kondisi fibrosis dan kerusakan sel-sel otot jantung (disfungsi sistol), sedangkan kadar apelin pada kondisi di antaranya (gagal jantung diastol/HFPEF) masih belum diketahui. Tujuan penelitian ini adalah menilai hubungan antara kadar apelin dan disfungsi diastol pada penderita gagal jantung dengan fraksi ejeksi normal.

\section{Metode}

Subjek penelitian adalah penderita hipertensi dengan gagal jantung dan fraksi ejeksi normal di Rumah Sakit Dr. Hasan Sadikin Bandung yang memenuhi kriteria inklusi dan tidak termasuk kreteria eksklusi. Kriteria inklusi penelitian yaitu hipertensi dengan gagal jantung dan fraksi ejeksi ventrikel kiri $\geq 40 \%$. Kriteria eksklusi penelitian yaitu atrial fibrilasi, penyakit jantung koroner, diabetes melitus, obesitas, dan gagal ginjal kronik. 
Penelitian ini merupakan epidemiologi klinik menggunakan desain potong lintang, dilakukan analisis data deskriptif yang dilanjutkan dengan analisis korelasi.

Data berupa kadar apelin yang diambil dari darah perifer dihubungkan dengan parameter disfungsi diastol yaitu tissue doppler imaging (TDI) atau rasio E/e' dan hubungannya dinilai dengan analisis korelasi dan regresi. Penelitian dilaksanakan di Instalasi Rawat Jalan Jantung dan Divisi Diagnostik Noninvasif Departemen Kardiologi dan Kedokteran Vaskular Rumah Sakit Dr. Hasan Sadikin Bandung. Penelitian ini dilaksanakan pada bulan Januari sampai dengan April 2014.

\section{Hasil}

Karakteristik subjek penelitian dapat dilihat pada Tabel 1. Terdapat 50 subjek penelitian terdiri atas subjek laki-laki sebanyak 24 (48\%) dan perempuan 26 (52\%), usia rata-rata 58,72 $(11,02)$ tahun, indeks massa tubuh rata-rata $24,14(3,88) \mathrm{kg} / \mathrm{m}^{2}$. Median tekanan darah sistol 130 (120-180) mmHg dan median tekanan darah diastol 90 (70-110) mmHg. Median frekuensi jantung 80 (70-91) x/menit. Median fraksi ejeksi median 65 (49-77)\%. Median durasi menderita hipertensi 5 (1-30) tahun. Obatobatan yang digunakan angiotensin converting enzyme inhibitor (ACEI), calcium channel blocker (CCB). Hasil pengukuran fungsi diastol pada subjek penelitian ini adalah TDI rata-rata 10,32, deceleration time rata-rata 228,2 detik, median rasio E/A 0,77 (0,43-1,53), median IVRT 92 (59177) detik. Median kadar apelin pada subjek penelitian ini 1.080,5 (993,2-1.113) pg/mL.

Analisis untuk mengetahui hubungan antara kadar apelin dan disfungsi diastol dilakukan dengan mempergunakan Uji korelasi Spearman Rank karena data kadar apelin tidak terdistribusi normal. Hasil yang didapatkan seperti yang ditunjukkan pada Tabel 2, 3, dan Gambar 1 yang

Tabel 1 Karakteristik Umum Subjek Penelitian

\begin{tabular}{|c|c|c|}
\hline Karakteristik & Rata-rata (SB) & $\begin{array}{c}\text { Median (Rentang) atau } \\
\text { Jumlah (\%) }\end{array}$ \\
\hline Usia & $58.72(11,02)$ & \\
\hline $\begin{array}{l}\text { Jenis kelamin } \\
\text { Laki-laki } \\
\text { Perempuan }\end{array}$ & & $\begin{array}{l}24(48 \%) \\
26(52 \%)\end{array}$ \\
\hline Tekanan darah sistol & & $130(120-180)$ \\
\hline Tekanan darah diastol & & $90(70-100)$ \\
\hline Frekuensi jantung & & $80(70-91)$ \\
\hline IMT (indeks massa tubuh) & $24,14(3,88)$ & \\
\hline Lama hipertensi & & $5(1-30)$ \\
\hline EF (ejeksi fraksi) & & $65(49-77)$ \\
\hline \multicolumn{3}{|l|}{ Fungsi diastol } \\
\hline TDI (tissue doppler imaging) & $10,32(2,40)$ & \\
\hline E/A (early/atrial (late) ventricular filling velocities) & & $0,775(0,43-1,53)$ \\
\hline Deceleration time & $228,2(33,82)$ & \\
\hline IVRT (isovolumic relaxation time) & & $94.5(70-177)$ \\
\hline Kadar apelin & & $1.080,5(999,3-1.113)$ \\
\hline \multicolumn{3}{|l|}{ Obat-obatan yang digunakan } \\
\hline ACEI (angiotensin converting enzyme inhibitor) & & $42(84 \%)$ \\
\hline ARB (angiotensin receptor blocker) & & $3(6 \%)$ \\
\hline Beta bloker & & $6(12 \%)$ \\
\hline CCB (calcium channel blocker) & & $27(54 \%)$ \\
\hline Diuretik & & $1(2 \%)$ \\
\hline
\end{tabular}

Keterangan: SB: Simpangan baku 
Tabel 2 Korelasi Kadar Apelin dengan Disfungsi Diastol (TDI)

\begin{tabular}{lcccc}
\hline \multicolumn{1}{c}{ Karakteristik } & Mean (SD) & Median (Rentang) & $\begin{array}{c}\text { Koefisien } \\
\text { Korelasi (r) }\end{array}$ & Nilai p \\
\hline Kadar apelin (pg/mL) & & $1080,5(993,2-1.113)$ & 0,345 & 0.14 \\
Disfungsi diastol (TDI) & $10,324(2,40)$ & & & \\
\hline
\end{tabular}

Keterangan: analisis korelasi menggunakan uji Rank Spearman, signifikan jika p<0,05

dipetakan secara scatter plot.

Dari Tabel 2 dapat dibuat simpulan bahwa terdapat korelasi positif sedang antara kadar apelin dan disfungsi diastol (TDI) dengan nilai $r=0,345$ dan p 0,014 $(<0,05)$. Hal ini berarti bahwa semakin tinggi kadar apelin maka semakin berat disfungsi diastol (TDI). Tabel 3 memperlihatkan bahwa korelasi yang bermakna hanya terjadi antara kadar apelin dan disfungsi diastol yang diukur menggunakan metode TDI, sementara dengan metode pemeriksaan fungsi diastol yang lain seperti IVRT, mitral inflow (E/A), dan deceleration time tidak menunjukkan korelasi yang bermakna.

\section{Pembahasan}

Hasil penelitian ini menunjukkan korelasi positif antara kadar apelin dan disfungsi diastol yang diukur dengan metode TDI (septal). Hal ini sesuai dengan hipotesis penelitian ini bahwa terdapat korelasi positif antara kadar apelin dan disfungsi diastol yang berarti bahwa semakin tinggi kadar apelin maka semakin berat disfungsi diastol yang dinilai dengan pemeriksaan TDI.

Penelitian ini sesuai dengan hasil penelitian yang telah dilakukan bahwa terdapat peningkatan pengeluaran apelin oleh sel-sel kardiomiosit yang mengalami mechanical offloading. Kondisi ini ditemukan pada populasi penderita dengan gagal jantung disertai hipertrofi ventrikel kiri.

Tabel 3 Korelasi Kadar Apelin dengan Berbagai Parameter Disfungsi Diastol

\begin{tabular}{lcc}
\hline Parameter & $\begin{array}{c}\text { Koefisien } \\
\text { Korelasi(r) }\end{array}$ & Nilai p \\
\hline TDI & 0,345 & 0,014 \\
E/A & $-0,27804$ & 0,0506 \\
IVRT & $-0,0160$ & 0,912 \\
Dec Time & 0,0208 & 0,885 \\
\hline
\end{tabular}

Keterangan: analisis korelasimen
Penelitian lain yang serupa yaitu penelitian oleh Kuba dkk. ${ }^{10}$ yang dilakukan pada tikus yang diberi perlakukan berupa pemberian beban tekanan kronik, hasil penelitian tersebut menunjukkan bahwa terjadi peningkatan kadar apelin pada tikus yang mengalami beban tekanan kronik disertai perubahan struktur jantung berupa hipertrofi otot-otot jantung dan kadar apelin menurun sesudah terjadi penurunan fungsi sistol jantung yang ditandai dengan penurunan fractional shortening pada jantung-jantung tikus tersebut. $^{12,16}$

Proses patofisiologi yang dapat menjelaskan bahwa peningkatan kadar apelin pada kondisi beban tekanan yang berat dijelaskan pada penelitian lain. yang menyatakan APJ receptor merupakan reseptor aktif dari apelin adalah reseptor yang peka terhadap rangsang mekanik (mechanosensor). Keadaan ini berdasarkan hasil penelitian yang menyatakan bahwa apelin dileluarkan oleh sel sel otot jantung saat terjadi rangsangan berupa beban tekanan yang tinggi. Aktivasi APJ ini mengakibatkan peningkatan ukuran sel-sel kardiomiosit dan menginduksi marker molekuler untuk hipertrofi. ${ }^{11}$

Penelitianlainyangmemberikan hasilberbeda dan penting untuk dibahas adalah penelitian

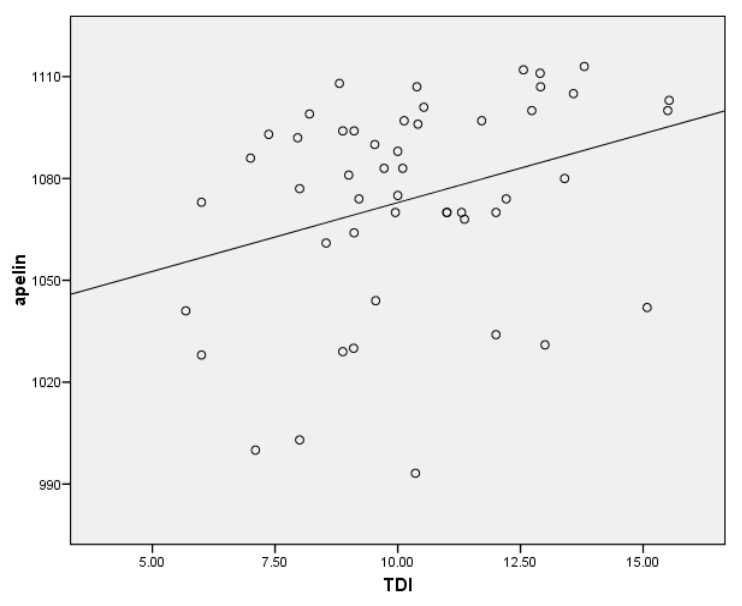

Gambar 1 Hubungan antara Kadar Apelin dan Disfungsi Diastol 
yang dilakukan oleh Przewlocka-Kosmala dkk. ${ }^{13}$ yang dilakukan pada populasi yang serupa dengan penelitian ini, yaitu penderita hipertensi dengan gagal jantung, namun memiliki hasil yang berlawanan dengan penelitian ini yaitu terdapat korelasi negatif antara kadar apelin dan disfungsi diastol yang diukur dengan metode strain. Hal ini berarti kadar apelin mengalami penurunan yang bermakna pada penderita hipertensi dengan disfungsi diastol dan sistol yang lebih berat. ${ }^{13}$

Przewlocka-Kosmala dkk. ${ }^{13}$ mengemukakan penurunan yang bermakna kadar apelin ini kemungkinan disebabkan bukan oleh sintesisnya yang menurun, namun oleh karena peningkatan degradasi dari peptida ini yang terjadi pada populasi hipertensi dengan disfungsi diastol yang lebih berat. Mekanisme lain yang dapat dipikirkan adalah teori yang menyatakan bahwa pada disfungsi diastol yang berat terjadi proses fibrosis otot jantung yang lebih bermakna sehingga hal ini menyebabkan sintesis apelin oleh sel-sel otot jantung semakin berkurang. Penelitian ini juga meneliti korelasi antara kadar apelin dan juga disfungsi diastol yang diperiksa dengan memakai metode TDI, namun hasilnya tidak menunjukkan korelasi yang bermakna. Analisis yang lebih lanjut menunjukkan bahwa nilai TDI pada subjek penelitian ini memiliki hasil yang relatif lebih tinggi daripada nilai TDI pada subjek penelitian ini. Hal ini menimbulkan dugaan bahwa ada kemungkinan pada nilai TDI tertentu korelasi positif antara kadar apelin dan disfungsi diastol akan menghilang bahkan berubah menjadi negatif, yaitu saat terjadi beban tekanan yang tinggi dan disertai proses fibrosis yang luas serta ditandai dengan penurunan kadar apelin, walaupun nilai TDI semakin tinggi. Nilai cut-off point saat terjadi hilangnya korelasi antara kadar apelin dan disfungsi diastol dan kemudian berubah menjadi negatif belum diketahui sampai saat ini.

Alat ukur yang berbeda untuk mengukur disfungsi diastol mungkin menjadi penyebab hasil yang berlainan pada kedua penelitian ini. Penelitian yang membandingkan metode TDI dengan strain untuk mengukur disfungsi diastol menyatakan bahwa TDI lebih sensitif untuk menilai beban tekanan pada ventrikel kiri, sementara strain lebih sensitif untuk menilai fibrosis interstitial dan viabilitas miokardium. Keadaan ini mendukung dugaan bahwa subjek penelitian pada penelitian Przewlocka-Kosmala dkk. ${ }^{13}$, mungkin memiliki proses fibrosis yang lebih luas dibandingkan dengan subjek pada penelitian ini sehingga dapat menghasilkan hasil akhir dengan simpulan yang berbeda bahkan berlawanan. ${ }^{16}$

Simpulan, hasil penelitian ini menunjukkan korelasi positif antara antara kadar apelin dan disfungsi diastol yang dinilai dengan TDI. Arti klinis apelin dikaitkan dengan hasil penelitian ini adalah pada disfungsi diastol, penilaian kadar apelin mungkin mempunyai potensi yang lebih besar untuk digunakan sebagai parameter prognostik dibanding dengan TDI karena hasil yang ada memperlihatkan bahwa kadar apelin memiliki korelasi positif dengan nilai TDI. Namun, pada nilai TDI tertentu korelasi positif ini akan menghilang bahkan berubah menjadi negatif yaitu saat terjadi beban tekanan yang tinggi, namun disertai proses fibrosis yang cukup luas. Nilai cut-off point apelin yang menunjukkan perubahan korelasi dengan disfungsi diastol (TDI) masih belum diketahui sampai saat ini dan membutuhkan penelitian lebih lanjut dengan populasi yang lebih mewakili seluruh gambaran klinis gagal jantung dengan fraksi ejeksi normal.

\section{Daftar Pustaka}

1. Sakata Y, Shimokawa H. Epidemiology of heart failure in Asia. Circ J. 2013;77(9):220917.

2. Dickstein K, Cohen-Solal A, Filippatos G, McMurray JJ, Ponokowski P, Poole-Wilson PA, dkk. ESC guidelines for the diagnosis and treatment of acute and chronic heart failure 2008. Eur Heart J. 2008;29(19):2388-442.

3. Udelson JE. Heart failure with preserved ejection fraction. Circulation. 2011;124(21);e540-3.

4. Diamond JA, Phillips RA. Hypertensive heart disease. Hypertens Res. 2005;28(3):191202.

5. Kai HKF, Tokuda K, Imaizumi T. Review: diastolic dysfunction in hypertensive hearts: roles of perivascular inflammation and reactive myocardial fibrosis. Hypertensive Res. 2005;28(6):483-90.

6. Nagueh SF, Appleton CP, Gillebert TC, Marino PN, Oh JK, Smiseth OA, dkk. Recommendation for the evaluation of left ventricular diastolic function by echocardiography. Eur J Echocardiog. 2009;10(2):165-93.

7. Japp AG, Cruden NL, Barnes G, van Gemeren N, Mathews J, Adamson J, dkk. The apelinAPJ system in heart failure patophysiologic relevance and theurapeutic potential. Biochem Pharmacol. 2008;75(10):1882-92. 
8. Falcao-Pires I, Leite-Moreira AF. Apelin: a novel neurohumoral modulator of the cardiovascular system. patophysiologic importance and potential use as theurapeutic target. Rev Port Cardiol. 2005;24(10):126376.

9. Scimia MC, Hurtado C, Ray S, Metzler S, Wei $\mathrm{K}$, Wang J, dkk. APJ acts as dual receptor in cardiac hypertrophy. Nature. 2012;488 (7411):394-8.

10. Kuba K, Zhang L, Imai Y, Arab S, Chen M, Maekawa Y, dkk. Impaired heart contractility in apelin gene-deficient mice associated with aging and pressure overload. Circ Res. 2007;101(4):e32-42.

11. Chandrasekaran B, Dar O, McDonagh T. The role of apelin in cardiovascular function and heart failure. Eur J Heart Fail. 2008; 10(8):725-32.

12. Shiong Chong K, Gardber RS, Morton JJ, Ashley EA, McDonagh TA. Plasma concentrations of the novel peptide apelin are decreased in patients with chronic heart failure. Eur J Heart Fail. 2006;8(4):355-60.

13. Przewlocka-Kosmala M, Mysiak A, Kosmala W. Reduced circulating apelin in essential hypertension and its association with cardiac dysfunction. J Hypertens. 2011;29(5):971-9.

14. Ashley EA, Powers J, Chen M, Kundu R, Fintersbach T, Caffarelli A, dkk. The endogenous apelin potently improves cardiac contractility and reduces cardiac loading in vivo. Cardiovasc Res. 2005;65(1):73-82.

15. Kasner M, Gaub R, Sinning D, Westerman D, Steendijk P, Hoffman W, dkk. Global strain rate imaging for the estimation of diastolic function in HFNEF compared with pressurevolume loop analysis. Eur J Echocardiogr. 2010:11(9);743-51.

16. Oh JK, Ji Park S, Nagueh SF. Established and novel clinical applications of diastolic function assessment by echocardiography. Circ Cardiovasc Imaging. 2011;4(4):444-55. 